Journal of Engineering Sciences, Assiut University, Vol. 37, No. 5, pp. 1157-1167, September 2009.

\title{
A NOVEL DIRECT TORQUE FUZZY CONTROLLER FOR PERMANENT MAGNET SYNCHRONOUS MOTOR DRIVE
}

\author{
A.A. Hassan Y.S. Mohamed A.M. El-Sawy E.G. Shehata \\ aahsn@yahoo.com \\ Electrical Eng. Dept., Faculty of Engineering, El -Minia University, Egypt
}

(Received July 12, 2009 Accepted August 5, 2009).

This paper studies the performance of the direct torque control of the permanent magnet synchronous motor drive. Direct torque control has several advantages such as simplicity, fast transient response, less parameter dependence, and absence of rotor position sensor. However, the high torque and flux ripples are considered the main drawback of the classical direct torque control especially at low speed. The torque and flux hystersis controllers are considered the main sources of these ripples. In this paper, a novel fuzzy logic direct torque controller is proposed to enhance the performance of the classical direct torque control. The hystersis controllers and lookup table are replaced by the proposed controller. Fuzzy controller determines the switching states for the inverter from the torque and flux errors and flux position angle. The proposed scheme still has the all advantages of the classical direct torque control. No additional measurements or control loops are required. Simulation works have carried out to evaluate the performance of the proposed fuzzy logic direct torque controller scheme. The waveforms of the torque, flux and speed of the classical direct torque control are compared to those obtained from the proposed scheme.

KEYWORDS: permanent magnet synchronous motor -fuzzy logic direct torque control - torque ripples.

\begin{tabular}{|llll|}
\hline \multicolumn{3}{c|}{ NOMENCLATURE } \\
$D$ & damping coefficient & $T_{L}$ & load torque \\
$i_{a b c}$ & three phase stator currents & $v_{a b c}$ & three phase stator voltages \\
$i_{d}, i_{q}$ & $\mathrm{~d}$ - q stator current components & $v_{d}, v_{q}$ & $\mathrm{~d}$-q stator voltage components \\
$i_{\alpha}, i_{\beta}$ & $\alpha-\beta$ stator current components & $v_{\alpha}, v_{\beta}$ & $\alpha-\beta$ stator voltage components \\
$J$ & moment of inertia & $\varphi_{\alpha}, \varphi_{\beta}$ & $\alpha-\beta$ stator flux components \\
$L_{d}$ & d-axis inductance & $\omega_{e}$ & angular stator frequency \\
$L_{q}$ & q-axis inductance & $\omega_{r}$ & actual motor speed \\
$P$ & number of pole pairs & $\omega_{r}{ }^{*}$ & reference motor speed \\
$R_{s}$ & stator resistance & $\theta_{e}$ & angular rotor position \\
$T_{e}$ & electromagnetic torque & $\lambda_{f}$ & permanent magnet flux \\
\hline
\end{tabular}




\section{INTRODUCTION}

Direct torque control (DTC) has received wide attention in the last few years. Because of its good characteristic, DTC becomes one of the most applied techniques in the field of drives. The advantages of the DTC can be summarized as: fast transient response, simplicity, less parameters dependence, and low switching frequency. Moreover, it has no need for rotor position sensor, and pulse width modulation [1].

A number of the publishers studied the application of DTC on the induction and synchronous motors [2-4]. However, the presence of high torque and flux ripples are considered the main problem of the DTC, especially at low speeds. This is attributed to the slow change in the inverter states. Thus, the inverter keeps the same states till the output of the hystersis controllers change.

Different techniques are studied to improve the performance of the classical DTC. Three level inverters are used to increase the available voltage vectors for reducing the torque and flux ripples [5]. However, the system becomes more complex and costly. Space vector modulation was employed also in a DTC scheme to reduce the torque and flux ripples [6-8]. However, these schemes suffer from the drawbacks of high switching losses in the inverter [6]. In [7-8], the voltage vectors are selected using five level hystersis controllers which increase the complexity of the system.

In [9], a constant switching frequency torque controller is proposed to replace the conventional hystersis controllers. However, two triangular waveform generators, two comparators, and PI controller are needed to perform that task. In [10], an equation is derived for the torque ripple in the induction motor. At each sample of time, an optimal switching instant is determined in order to satisfy minimum torque ripple content. However, the speed signal is needed for that system. In addition, the ripple equation depends on the motor parameters.

Predictive direct torque control for PMSM was studied in [11]. The predictive torque and flux are used to select the suitable voltage vector and switching time at each sample. However, the time derivative of the torque (required for predictive control) depends on the stator voltage, stator current, permanent magnet flux, and the rotor position [12]. In [13], the vector control and the DTC are combined to reduce the torque ripples in the induction motor. However, this technique is sensitive to the variation of the rotor time constant.

Intelligent controllers such as fuzzy or neuro-fuzzy controllers are used to solve the problems of the classical DTC [14-20]. However, the torque and flux ripples still high in these techniques, and most of them depends mainly on the speed signal.

In this paper, the fuzzy logic direct torque controller (FLDTC) is used to improve the performance of the classical DTC. The hysteresis controllers and the lookup table are replaced by the proposed controller. The FLDTC is designed to provide the switching states of the inverter using the torque error, stator flux error and stator flux angle. The controller inputs are fuzzified into fuzzy subsets to optimize the selection of the stator voltage vector. The proposed technique still has the same advantages of the classical DTC. Simulation works at different operating conditions are performed to compare the results of the proposed scheme with the classical direct torque control. The results show that a pronounced reduction in torque and flux ripples is evident in the proposed scheme. 


\section{MATHEMATICAL MODEL}

The permanent magnet synchronous motor (PMSM) with surface mounted permanent magnets can be described in the $\mathrm{d}-\mathrm{q}$ synchronous reference frame as follows:

$v_{d}=R_{s} i_{d}+L_{d} d i_{d} / d t-\omega_{e} L_{q} i_{q}$

$v_{q}=R_{s} i_{q}+L_{q} d i_{q} / d t+\omega_{e} L_{d} i_{d}+\omega_{e} \lambda_{f}$

The stator flux linkage can be obtained from the following equations:

$\phi_{\alpha}=\int\left(v_{\alpha}-R_{s} i_{\alpha}\right) d t$

$\phi_{\beta}=\int\left(v_{\beta}-R_{s} i_{\beta}\right) d t$

The electromagnetic torque can be estimated using the stator current and the stator flux components as follows:

$$
T_{e}=1.5 P\left(i_{\alpha} \phi_{\beta}-i_{\beta} \phi_{\alpha}\right)
$$

\section{DIRECT TORQUE CONTROL}

The main idea of DTC is based on the control of the amplitude and angular speed of the stator flux linkage. It involves the direct choice of the optimum switching modes, and so the stator voltage vector, in order to keep the flux and torque errors within a predetermined band limit. Figure (1) shows the block diagram of the classical DTC technique. The torque and flux errors $e_{T}, e_{\varphi}$ are defined as the difference between the reference and the estimated values of torque and flux; i.e.

$e_{T}=T^{*}-\hat{T} \quad$ and $\quad e_{\varphi}=\varphi^{*}-\hat{\varphi}$

The classical DTC employs hysteresis comparators instead of flux and torque controllers. The outputs of the hysteresis controllers $(\tau, \Phi)$ and the number of sector $(\theta)$ are fed to the lookup table to select the switching $\operatorname{logic}\left(\mathrm{S}_{\mathrm{a}, \mathrm{b}, \mathrm{c}}\right)$ necessary for operating the inverter switches. Table (1) shows the switching states for controlling the amplitude and direction of the stator flux.

\section{FUZZY LOGIC DIRECT TORQUE CONTROLLER}

In spite of the many advantages of the DTC, the ripples of the torque, flux and speed are considered the main problem. The hystersis controllers are the main reason beyond this problem. Large ripples in flux and torque appear especially at low speed. Fuzzy logic controller is proposed to replace the hystersis controllers and lookup table, without losing any advantage of DTC. The block diagram of the proposed FLDTC scheme is illustrated in Fig.(2). The torque error, flux error and stator flux angle are fuzzified into several fuzzy subsets to optimize the selection of the voltage vector. For speed control based DTC, a proportional- integral (PI) controller is used in the outer loop to develop the torque command. 


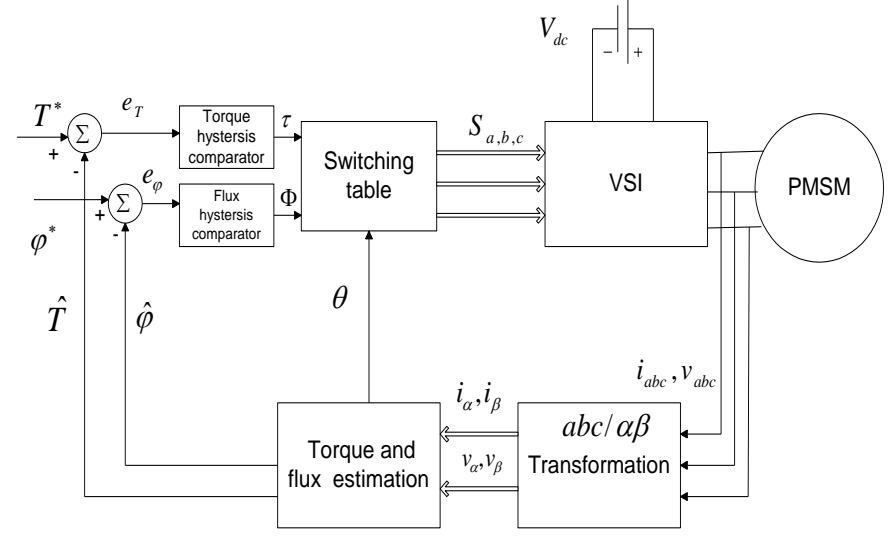

Fig.(1) Block diagram of classical DTC scheme.

Table (1) Inverter Switching States

\begin{tabular}{|c|c|c|c|c|c|c|c|}
\hline \multicolumn{2}{|c|}{$\theta$} & $\theta_{1}$ & $\theta_{2}$ & $\theta_{3}$ & $\theta_{4}$ & $\theta_{5}$ & $\theta_{6}$ \\
\hline \multirow{2}{*}{$\phi=1$} & $\tau=1$ & 110 & 010 & 011 & 001 & 101 & 100 \\
\cline { 2 - 8 } & $\tau=0$ & 101 & 100 & 101 & 010 & 011 & 001 \\
\hline \multirow{2}{*}{$\phi=0$} & $\tau=1$ & 010 & 011 & 001 & 101 & 100 & 110 \\
\cline { 2 - 8 } & $\tau=0$ & 001 & 101 & 100 & 110 & 010 & 011 \\
\hline
\end{tabular}

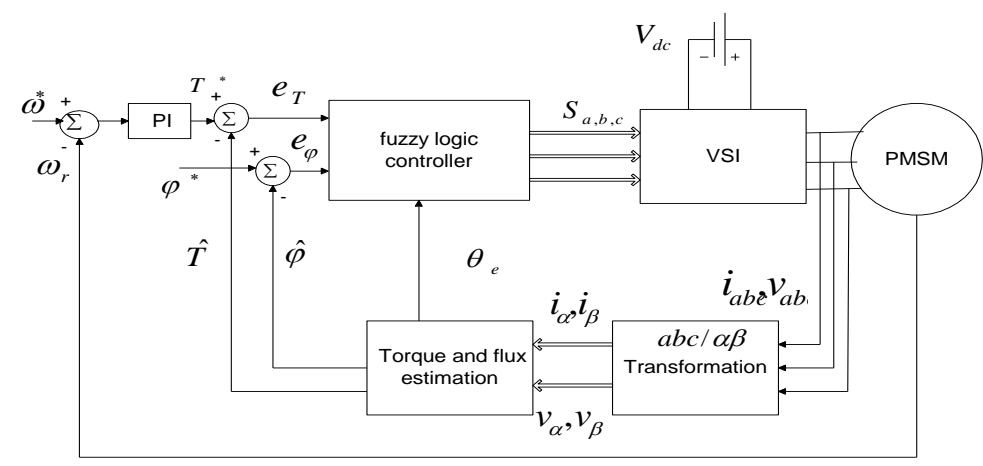

Fig.(2) Block diagram of proposed FLDTC scheme.

\subsection{Fuzzy Controller Design}

The fuzzy controller has three inputs and one output. The torque error $\left(e_{T}\right)$, flux error $\left(e_{\varphi}\right)$ and the stator flux angle $(\theta)$ are input variables. The voltage vector $(\mathrm{u})$ is the output variable. The torque error is fuzzified into $E_{T}$ including four fuzzy subsets (PL,PS,NS,NL). The flux error is fuzzified into $\mathrm{E}_{\Phi}$ including two fuzzy subsets $(\mathrm{P}, \mathrm{N})$. 
The stator flux angle ranges from 0 to $2 \Pi$ and fuzzified into 12 subsets $\left(\theta_{1}: \theta_{12}\right)$. The output voltage vector of the fuzzy controller contains six voltage vectors (1: 6). So, it is not required to be fuzzified into subsets. A fuzzy singleton set will be used to fuzzify the output voltage vector $\left(\mathrm{u}_{1}: \mathrm{u}_{6}\right)$. Figure (3) shows the membership functions of the input and output variables.

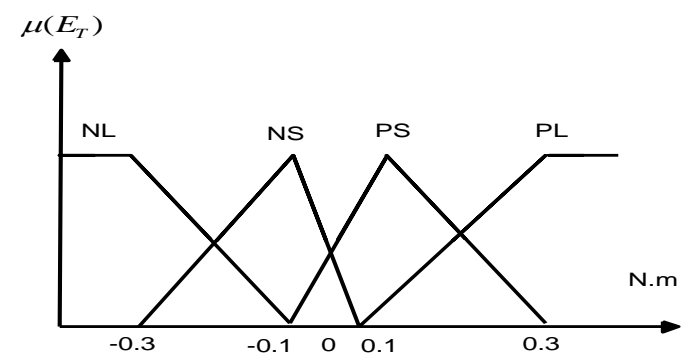

(a) Membership function of $\mathrm{E}_{\mathrm{T}}$

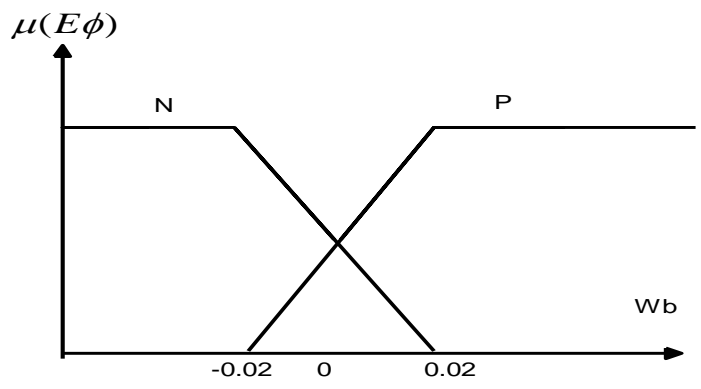

(b) Membership function of $\mathrm{E}_{\Phi}$

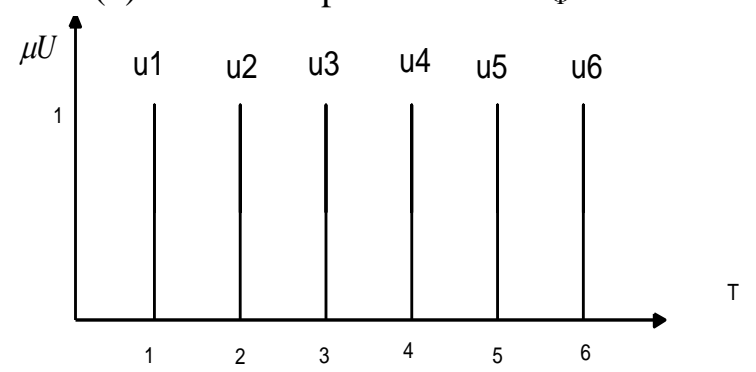

(c) Membership function of $\mathrm{U}$

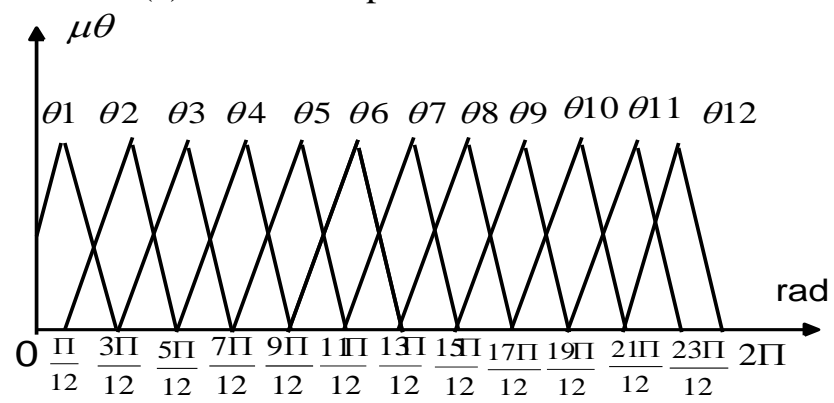

(d) Membership function of $\theta$

Fig.(3) fuzzy Membership function of inputs and output variables 


\subsection{Fuzzy Rules for DTC}

Fuzzy rules are selected to give the output voltage vector which produces the desired change in the torque and flux. Each control rule can be described using the input variables $\mathrm{E}_{\mathrm{T}}, \mathrm{E}_{\Phi}, \theta$ and the voltage vector $\mathrm{U}$. The ith rule Ri can be expressed as:

Ri: if $E_{T}$ is $A i, E_{\Phi}$ is $B i, \theta$ is $C i$, then $U$ is $N i$

Where $\mathrm{Ai}, \mathrm{Bi}, \mathrm{Ci}$ are the fuzzy subsets and $\mathrm{Ni}$ is a fuzzy singleton set. The total number of rules is 97 rules. Table (2) contains 96 rules. If the torque error is within the range (-.05: 0.05), the zero voltage vector will be selected regardless the values of the other fuzzy inputs. This is considered as the final rule. The interface method used in this paper is Mamdani's procedure based on max-min decision [8-9]. The firing strength $\alpha$ i for ith rule is expressed as:

$\alpha_{\mathrm{i}}=\min \left(\mu\left(\mathrm{E}_{\mathrm{T}}\right), \mu\left(\mathrm{E}_{\Phi}\right), \mu(\theta)\right)$

By fuzzy reasoning, Mamdani's minimum procedure gives

$\mu^{\prime} \mathrm{N}_{\mathrm{i}}(\mathrm{n})=\min \left(\alpha_{\mathrm{i}}, \mu \mathrm{N}_{\mathrm{i}}(\mathrm{n})\right)$

The membership function of the output is given by:

$\mu \mathrm{N}_{\mathrm{i}}(\mathrm{n})=\max \left(\mu^{\prime} \mathrm{N}_{\mathrm{i}}(\mathrm{n})\right)$

The output fuzzy subsets are crisp. So, the maximum criterion method is used for defuzzification where, the control output is the fuzzy output value which has the maximum possibility distribution [8].

Table (2) Fuzzy rules for DTC

\begin{tabular}{|c|c|c|c|c|c|c|c|c|c|c|c|c|c|}
\hline & $E_{T}$ & 1 & $\theta 2$ & $\theta$ & $\theta 4$ & $\theta 5$ & $\theta 6$ & $\theta 7$ & $\theta 8$ & $\theta 9$ & $\theta 10$ & $\theta 11$ & \\
\hline & & & U2 & O3 & & U4 & U4 & U5 & J5 & & 6 & U1 & J1 \\
\hline & & & & & & & & & & & & & \\
\hline & & & $\mathrm{U}$ & & & & & & & & 6 & & \\
\hline & & & U6 & & & U2 & & & U3 & U4 & U4 & J5 & J5 \\
\hline & & & & & & & & & & & & & \\
\hline & $\mathrm{P}$ & & $\mathrm{U} 4$ & & & $\mathrm{U}$ & & & U1 & & U2 & & U3 \\
\hline & $\mathrm{N}$ & & U & & & $\mathrm{U}$ & & & & & U4 & & U5 \\
\hline & & & & & & U1 & & & $\mathrm{U} 2$ & $\mathrm{U} 3$ & U3 & & \\
\hline
\end{tabular}

\section{SIMULATION RESULTS}

Simulation works are carried out to evaluate the proposed FLDTC scheme. The stator flux and torque hystersis band amplitudes are chosen as $0.01 \mathrm{~Wb}$., and 0.01 N.m respectively. The gains of the PI speed controller are selected as: $\mathrm{Kp}=0.5$, and $\mathrm{Ki}=3$. The sampling frequency $=10 \mathrm{Khz}$. The reference stator flux is $0.5 \mathrm{~Wb}$. The parameters of the PMSM used for simulation procedure are listed in table (3).

Firstly, the classical and the proposed schemes are tested at high speeds. The reference speed is assumed to be increased linearly from zero to $1500 \mathrm{rpm}$ in $0.4 \mathrm{sec}$. The load torque is changed from 2 N.m ( 0.67 p.u) to 3 N.m (1 p.u) at $t=4$ sec. Also, 
the stator resistance is assumed to be changed from 6 to $9 \mathrm{ohm}$ at $\mathrm{t}=6 \mathrm{sec}$. Figures (4) and (5) show the simulation waveforms of the classical DTC and proposed FLDTC respectively. It is clear that the speed waveform of the FLDTC is smoother than that of the classical DTC. This means that the motor will operate more quietly. Small dips occur in the actual speed at the instant of stepping the load torque or stator resistance. The current waveform of the classical DTC is highly distorted than in the case of the FLDTC scheme. Also, the torque and flux ripples are reduced by more than $50 \%$. On the other hand, the fast transient response of the classical DTC is not lost in the proposed scheme.

Table (3) Parameters and data of the PMSM

\begin{tabular}{|c|c|c|c|}
\hline No. of pole pairs & 2 & Base speed $\omega(\mathrm{rpm})$ & 1500 \\
\hline $\operatorname{Rs}(\Omega)$ & 6 & Magnet flux linkage $(\mathrm{wb})$ & 0.337 \\
\hline $\mathrm{Lq}(\mathrm{H})$ & 0.1024 & Rated torque $($ N.m $)$ & 3 \\
\hline $\mathrm{Ld}(\mathrm{H})$ & 0.0448 & $\mathrm{Vdc}($ volt $)$ & 300 \\
\hline
\end{tabular}

The proposed scheme has been tested also at low speed to evaluate its effectiveness. Figures (6) and (7) depict the simulation results of the classical and proposed scheme respectively. The reference speed is assumed to be increased linearly from zero to $100 \mathrm{rpm}$ in $0.2 \mathrm{sec}$, and then kept constant at this value. The load torque is changed suddenly from 3 ( 1 p.u) to 4 (1.33 p.u) N.m at $t=4$ sec. It is clear that the speed response of the FLDTC has less ripple magnitude than of the classical DTC scheme. Also, the ripple content in the current waveform of the proposed FLDTC scheme is very low. The torque and flux ripples are reduced by about $50 \%$.
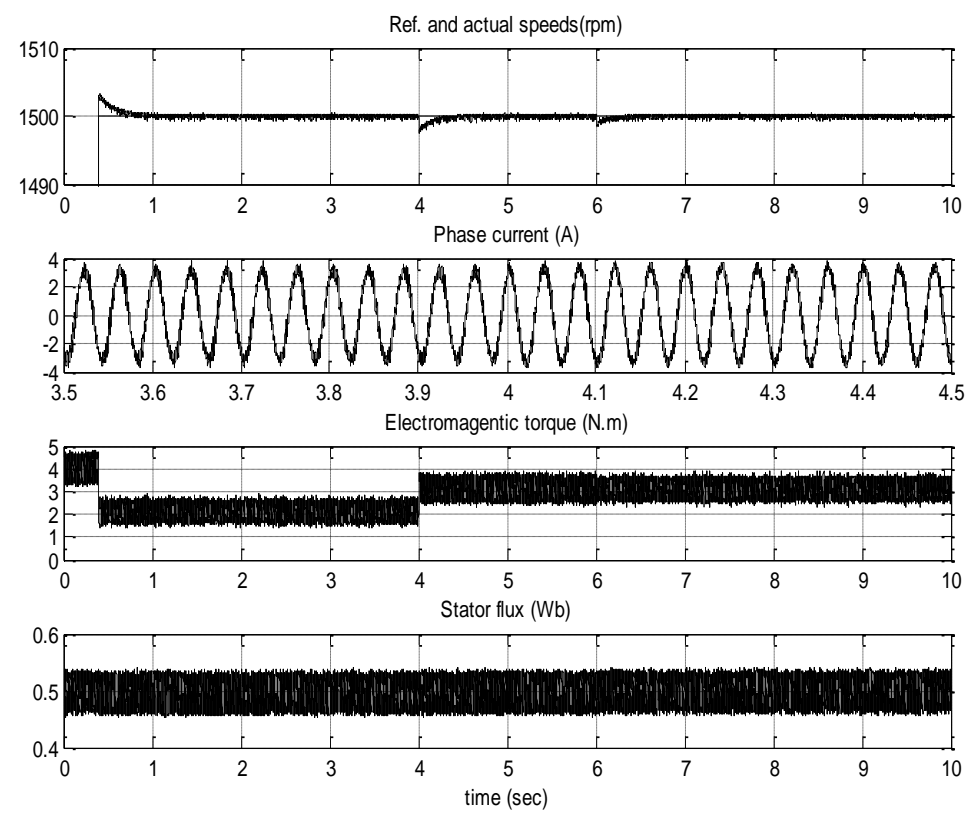

Fig.(4) Response of the classical DTC at high speed. 

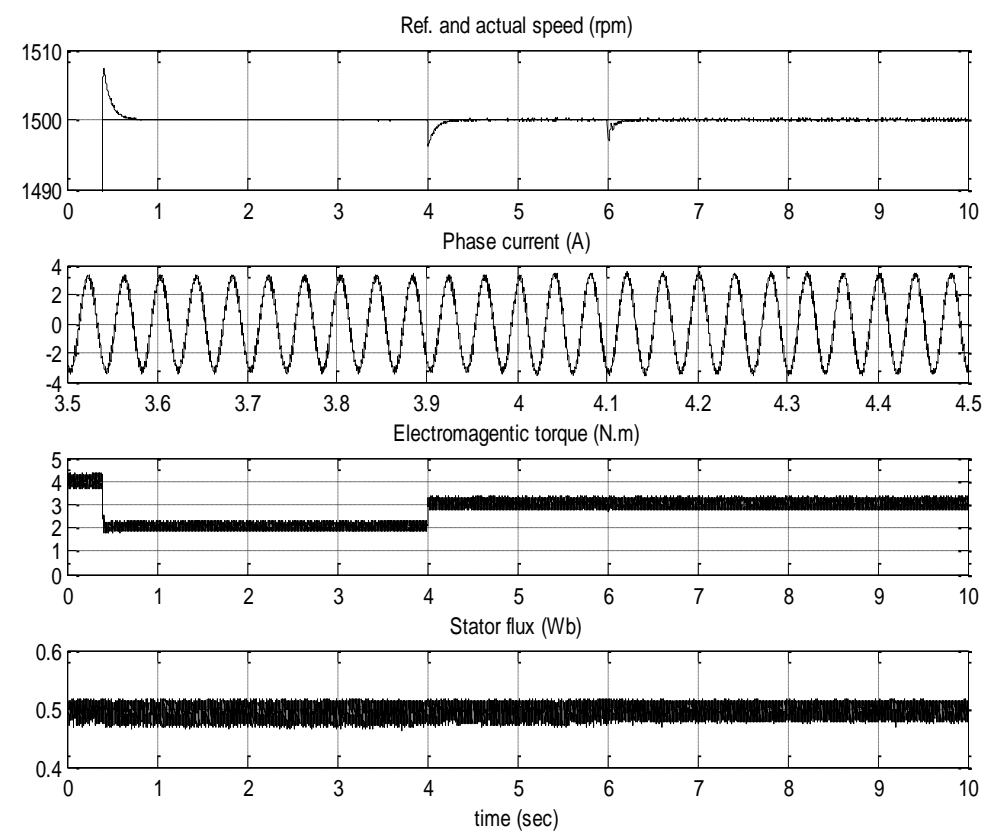

Fig.(5) Response of the proposed FLDTC at high speed.
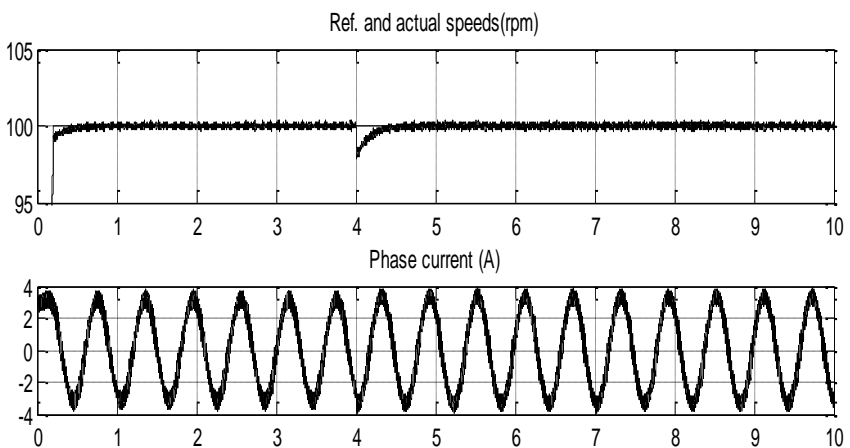

Electromagentic torque (N.m)
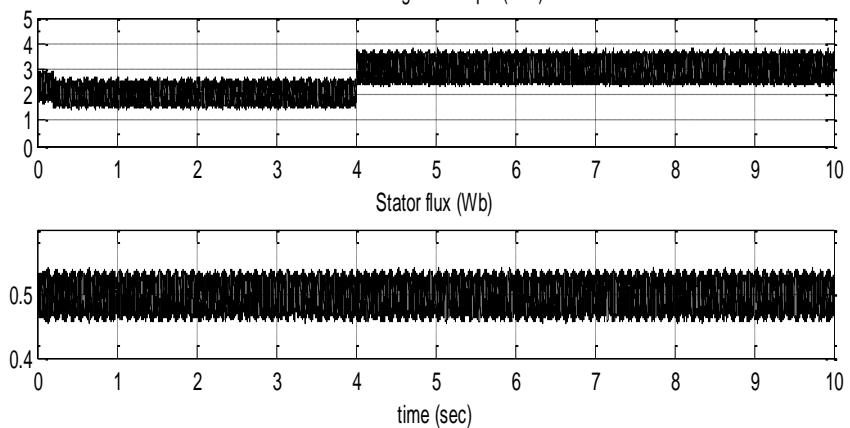

Fig.(6) Response of the classical DTC at low speed. 

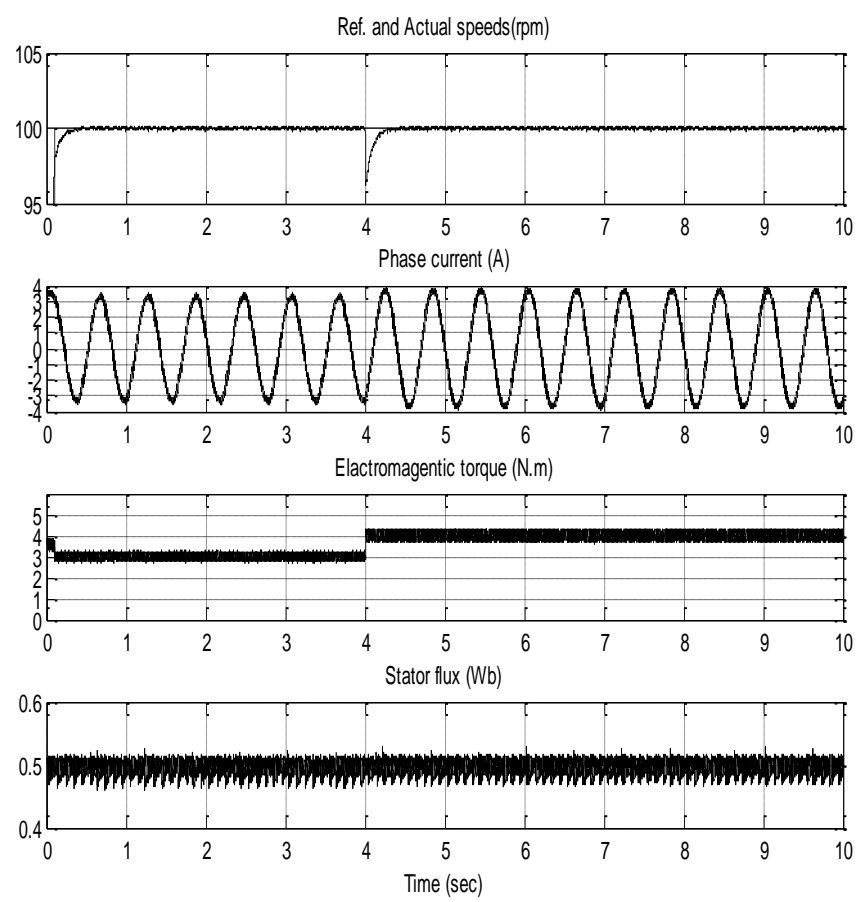

Fig.(7) Response of the proposed FLDTC at low speed.

\section{CONCLUSIONS}

The torque and flux ripples degrade the performance of classical DTC. The hystersis comparators are the main source of these ripples. Fuzzy logic controller is proposed in this paper to replace the hystersis comparators and lookup table. The rules of the fuzzy controller are designed to provide the suitable inverter switching states. Simulation works are performed to compare the performance of both classical and proposed scheme. The results show that the proposed scheme provides better performance at low and high speeds. Thus, pronounced improvement in the speed, current, torque, and flux waveforms are noticed with either load disturbance or stator resistance mismatch.

\section{REFERENCES}

[1] I. Takahashi, and T. Noguchi, "A new quick-response and high-efficiency control strategy of an induction motor." IEEE Trans. On Indust. Appl., 1986, IA-22(5), 820-7.

[2] L. Zhong, M.F. Rahman, W.Y.Hu, K. W. Lim, and M.A.Rahman, "A direct torque controller for permanent magnet synchronous motor drives," IEEE Trans. On Energy Conversion, Vol. 14, No. 3, Sept. 1999, pp.637-642.

[3] L. Zhong, M.F. Rahman, K. W. Lim, and L.Zhong, "A direct torque controlled interior permanent magnet synchronous motor drive incorporating field weakening " IEEE Trans. On Indust. Appl, Vol. 34, No.6, March 1998, pp.1246-1253.

[4] Lixin Tang, M. F. Rahman, L. Zhong, , and Md.Enamul Haque, "Problems associated with the direct torque control permanent magnet synchronous motor 
drive and their remedies ", IEEE Trans. On Indust. Electronics, Vol. 51, No. 4, August 2004, pp. 799-809.

[5] Giuseppe S.Buja, Marian P.Kazmierkowski," Direct torque control of PWM inverter- fed ac machine- a survey." IEEE Trans. On Indust. Electronic, Vol. 51, No. 4, Augest 2004, pp. 744-757.

[6] Lixin Tang, M. F. Rahman, L. Zhong, and Yuwn Hu, "A novel direct torque controlled Interior permanent magnet synchronous motor with low ripple in flux and torque and constant switching frequency", IEEE Trans. On Energy Conversion, Vol. 19, No.2, March 2004, pp.346-354.

[7] Demenico Casadei, Giovanni Serra, Angelo Tani," Implementation of a Direct Torque Control Algorithm for Induction Motors Based on Discrete Space Vector Modulation." IEEE Trans. On Power Electronic, Vol. 15, No. 4, July 2000, pp. 769-777.

[8] Xin Wei, Dayue Chen and Chunyu Zhao, " Minimizing of torque ripple of direct torque controlled induction machine by improved discrete space vector modulation" Electric power systems research 72(2004) 103-112

[9] Nik Rumzi Nik Idris, A.H.Mahamed Yatim." Direct torque control of induction motor with constant frequency switching and reduced torque ripple." IEEE Trans. On Indust. Electronic, Vol. 51, No. 4, August 2004, pp. 758-767.

[10] Jun-Koo Kang and Seung-Ki Sul," New direct torque control of induction motor for minimum torque ripple and constant switching frequency,", ", IEEE Trans. On Indust. Appl, Vol. 35, No. 5, Sep 1999, pp. 1076-1081.

[11] Mario Pacas, Jurgen Weber, "Predictive Direct Torque Control for the PM Synchronous Machine” IEEE Trans. On Indust. Electronic, Vol. 52, No. 5, Oct 2005, pp. 1350-1356.

[12] Thpmas J. Vyncke, Rene K. Boel and A.A. Melkebeek." Direct Torque Control of Permanent Magnet Synchronous Motors- An Overview." $3^{\text {RD }}$ IEEE Benelux Young Researchers Symposium in Electrical Power Engineering 27-28 April 2006, Ghent, Belgium.

[13] Y. Kumsuwan, S. Premrudeepreechacharn, and Hamid A. Toliyat." Modified direct torque control method for induction motor drives based on amplitude and angle control of stator flux" Electric power systems research 78(2008) 1712-1718

[14] Pawel Z. Grabowski, Marian P. Kazmierkowski, Bimal K. Bose and Frede Blaabjerg. " A simple direct torque neuro-fuzzy control of PWM-inverter-fed induction motor drive." IEEE Trans. On Indust. Electronic, Vol. 47, No. 4, Augest 2000, pp. 863-869.

[15] L. Romeral, A. Arias, E. Aldabas, and M. G. Jayne," Novel direct torque control (DTC) scheme with fuzzy adaptive torque ripple reduction", IEEE Trans. On Indust. Elect., Vol. 50, No. 3, June 2003, pp 487-492.

[16] A. Arias, L. Romeral, E. Aldabas, and M. G. Jayne "Stator flux optimized Direct Torque Control system for induction motors" Electric power systems research 73(2005) pp 257-265

[17] J. YANG, and J. HUNAG " A New Full Speed Range Torque Control Strategy For Induction Machine" Proceeding of the Third International Conference on Machine Learning and Cybernetics, Shanghai, 26-29 Augest 2007, pp 568- 573 
[18] M. Vasudevan and R. Arumugam “ High- Performance Adaptive Intelligent Direct Torque Control Scheme For Induction Motor Drives" KMITL sci. Tec. J. Vol 5 No. 3 Jul. Dec 2005.pp 559-576

[19] L. CHEN, K. FANG, and Z. HU “ A scheme of Fuzzy Direct Torque Control for Induction Machine" Proceeding of the Third International Conference on Machine Learning and Cybernetics, Guangzhou, 18-20 August 2005, pp 803- 807

[20] H. I. Okumus " A New Torque Controller for Direct Torque Controlled Induction machine Drives." Proceeding of middle east power system conference, MEPCON'2008, pp 244-248

\section{التحكم المبتكر الضبابي المباشر في عزم المحرك التزامني ذات الأقطاب المغناطيسية}

\section{الائمة}

أحد عبد التواب حسن أحد محد الصاوي بحيي سبي محد عماد جمبل شحاتة

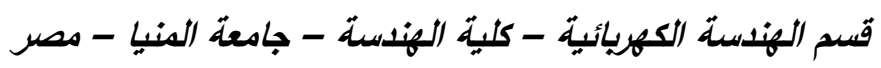

هذا البحث يدرس أداء التحكم المباشر في العزم (Direct Torque Control) للمحرك التزامني ذو الأقطاب المغناطيسية الذائمة. و يتميز التحكم المباشر في العزم بعدة مميزات و هي بساطة لنظام التحكم وقلة الأعتماد علي معاملات المحرك و عدم الاحتباج الي حساس سرعة. لكن تعتبر النسبة العالية

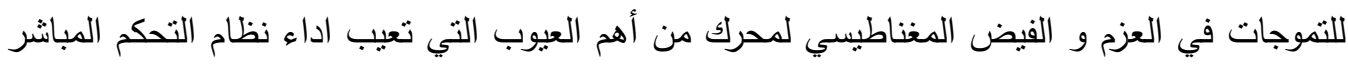
التقليدي خصوصا عند السرعات البطيئة. و تعتبر التحكمات التخلفية (Controllers Hysteresis) هي المسبب الرئيس لهذه التموجات. في هذا البحث يقترح المبتكر الضبابي المنطقي المباشر في العزم لتحسين أداء التحكم المباشر التقليدي.

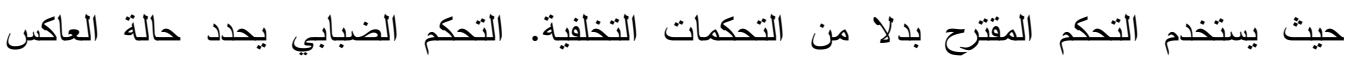

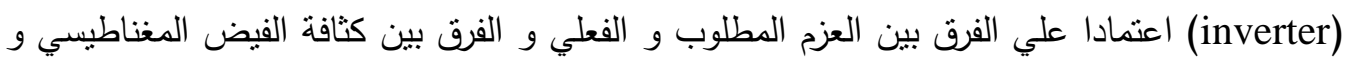

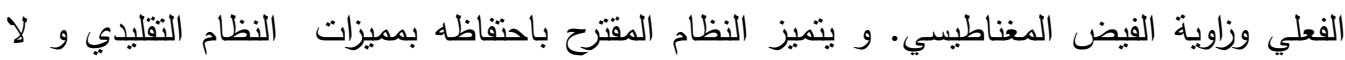
يحتاج الي أي قياسات أخري. للحكم علي اداء التحكم المقترح تم عمل محاكاة بالكمبيوتر . وتم مقارنة شكل موجات العزم والنييار و العزم المغناطيسي و سرعة المحرك لكل من التحكم النقليدي و المقترح. حيث أوضحت النتائج عن تحسين واضح في هذه الموجات. 